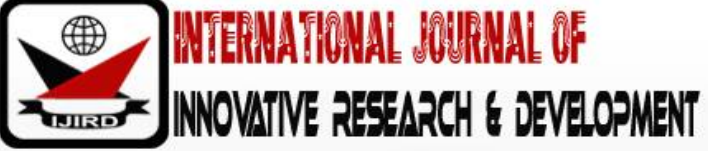

ISSN 2278 - 0211 (Online)

\section{Credit Facility and Agricultural Development in Adamawa State, Nigeria}

\author{
Dr. Chris AC-Ogbonna \\ Senior Lecturer, Department of Economics, Veritas University Abuja, Nigeria \\ Godwin Michael Gidado \\ Deputy Manager, Operations Department, Petroleum Equalization Fund, Abuja, Nigeria
}

\begin{abstract}
:
This study investigated the impact of credit facilities in stimulating agricultural development in Adamawa State, North East Nigeria. The study which is a survey research used primary data collected through questionnaires to respondents with an interview session. Frequency distribution tables, percentages and logistic Regression Analysis were used in data analysis. Our findings show that credit guaranty schemes on agriculture (CGSA) have positive impact on the agricultural sector in Adamawa State. The Central Bank of Nigeria's anchor borrower's loan (CBABL) is a positive development in financing agricultural production in Adamawa State. Bank Credits to Agricultural sector (BCA) at reduced interest rate has affected agricultural output in the State positively. Various Government Intervention Schemes (GIS) has ensured sustainable food security in Adamawa State. Based on these findings, the following recommendations are made; concerted efforts should be made to increase the level of agricultural output in Nigeria by providing incentives to farmers. Government should increase the level of Credit guaranty schemes to farmers which will impact positively on the development of agricultural sector in Adamawa State. Awareness on the Central Bank of Nigeria's anchor borrower's loan should be made to farmers because of its positive impact on the development of agricultural production in Adamawa State. Bank Credits on Agriculture particularly from Bank of Agriculture (BOA) should be increased at a reasonably low interest rate to boost agricultural output in Adamawa State. Government Intervention Schemes such as Agricultural extension services should be enhanced to ensured sustainable food security in Adamawa State.
\end{abstract}

Keywords: Evaluation, credit facility, sustainable, agricultural development, Adamawa State

\section{Background to the Study}

The provision of this facilities are said to have improved the economic climate for agricultural development and poverty alleviation in some countries such as facilitating individual farmer's access to inputs and improved technology which has accelerated productivity, improved income distribution among farmers etc. Given these importance, the provision of credit facilities by most banks especially the Agricultural development Banks to the agricultural sector have not been remarkable in the improvement of most peoples' welfare either because most of the funds made available are not tailored towards the sector that provided great concern to the less privileged farmers in the rural areas or because of the stringent conditions attached to most of the loans and advances by the banks thus depriving the less privilege mostly poor farmers access to the funds.Nigeria's food security and economy at large is on the line as inadequate storage and processing facilities which should have been provided by the value chain has become the major cause of the huge postharvest losses of farm produce that is a daunting challenge to farmers in the country. While local farmers are able to meet most of the country's demand for tomatoes, a staple food in almost all Nigerian homes, post-harvest losses has created a great gap between the demand and supply figures.

The resources of the entire world should be developed to the fullest with available means as a whole which can be attained only by the efficient and rational use of such resources. These resources depend on the importance attached to them. The significance of agricultural resource in bringing about economic growth and sustainable development of a nation cannot be underestimated. Agriculture contributes to the growth of the economy, provides employment opportunities for the teaming population, exports revenue earnings and eradicates poverty in the economy. Over the years in Nigeria, the volume of credit facility into the economy has continued to increase. The volume of credit facility to the private sector increased from N6.23million in 1980 to N29.21 billion in 2010. Credit to private sector as a percentage of Gross Domestic Product (GDP) increased from 12.56 percentages in 1980 to 18.59 percentage in 1993. The figure increased to 37.78 percentage point in 2010. This credit creation to the economy is expected to assist in leveraging economic agents, augment their vulnerability to economic shocks and ultimately enhance economic productivity. However, over the years, the economic growth has remained very low except for the last four years when marginal increases were recorded. This puzzle has raised concern as to the impact of bank credit on economic growth in Nigeria 
especially in the agricultural sector. This explains the rationale for the study. Specifically, the study evaluate the effects of bank credit on the growth of the real sector namely agriculture.

\section{Statement of the Problem}

In the 1960's, agriculture accounted for $65-70 \%$ of total exports; it fell to about $40 \%$ in 1970 's and crashed to less than $2 \%$ in 1990s to date. The decline in the agricultural sector was largely due to rise in crude oil revenue in the early 70's. Low agricultural output has a negative effect on the Nigerian economy as a whole. It was in recognition of this fact that the Federal Government at various periods put in place credit policies, institutions and schemes that could facilitate the flow of agriculture. A report from the Federal Ministry of Agriculture and Rural Development (2016) put the demand for tomatoes in Nigeria at 2.2 million tons and the supply at 800,000 tons. According to the ministry, the actual quantity of tomatoes harvested is 1.5 million tons but 700,000 tons are actually lost to post-harvest bottlenecks. National Planning Commission (2011) also revealed that agriculture contributed 348.7 billion recorded nation's economy in 2012 as against 335.18 billion recorded in 2013. The report noted that the sectors valued-added stood at $\$ 348.7$ billion compared with $\$ 335.18$ billion recorded in 2011, indicating a growth rate of $3.97 \%$ as against $5.64 \%$ in 2011 . It added, that the contribution of agriculture to overall real gross domestic product. Growth was $24.41 \%$ in 2012, compared with $31.41 \%$ in 2011. Growth was led by crop production, which accounted for $20.46 \%$ of the overall economic growth in 2012 compared with $24.41 \%$ in 2011.

The major problem confronting the agricultural sector today however is in its inability to contribute to foreign exchange earnings and increased productivity. Despite credit facilities to farmers, co-operative societies and agro industries to enhance productivity, agriculture has not actually assumed its rightful place in the nation's GDP especially in Adamawa State. It would be extremely difficult to attain long run sustainable growth in the state, if not impossible without addressing the problem of the agricultural sector. This raises the question of what has been the impact of credit facilities in stimulating agricultural development in Adamawa State.There was a sharp decline in export crop production, while food production increased only marginally. Thus, domestic food supply had to be augmented with large imports. "Food import bill rose from a mere $\$ 113.88$ million annually in 1970-1974 to \$1,964 million in 1991" (CBN, 2003).Theoretically, inputoutput theory in economics posits that input determines output. More so, Keynes postulated that increased government spending boosts economic growth. In the case of Nigeria, there has been a conflicting view about spending on agriculture just as we can see from various scholars stated above. Therefore, there is the need to examine the extent to which government finance has affected agricultural productivity in Nigeria.

\section{Objectives of the Study}

The main objective of this study is to evaluate the effect of credit facilities in stimulating agricultural production in Adamawa State.

\section{Literature Review and Theoretical Framework}

Nigerian economy depended on agriculture in the past decades and is still a major sector despite the oil boom; basically it provides employment opportunities for the teeming population, eradicates poverty and contributes to the growth of the economy. The agricultural sector in Nigeria has been bedeviled by a number of problems. This has affected its productivity and efficiency. Hence, Bernard (2009) believes that "Inadequate funding of the agricultural sector has constituted an obstacle to increased agricultural output" However, "from a nominal point of view, it is evident that in Nigeria, government spending on agriculture continued to increase over the years while empirical evidence have revealed that the performance of the agricultural sector has been inadequate" (Ekerete, 2000). The agricultural sector in Nigeria which was the mainstay of the economy is no longer performing the lead role it was known for. By mid-1970's Nigeria's agriculture started to experience problems. Agricultural exports began to decline and food shortages started emerging.Bank Credit is the amount extended out with a future date of payment. The NDIC prudential guide lines of 1990 however, provides a wider of credit, and this includes aggregate of all loans, advances, overdrafts, commercial papers, Banker acceptance, bills discounted. Leases and guarantee (NDIC, 1990). Muftau (2003), on the other hand, defines agricultural credit as grants given to farmers and ranch operators to assist in planting and harvesting crops to support the feeding and care of livestock. Credit to agricultural sector could take the form of an overdraft, short-term, medium- term or long-term depending on the purpose and gestation period of the project. Such credits granted to framers to purchase inputs are paid directly to the suppliers who must furnish the bank with evidence of delivery. This is done to avert diversion of fund, which is common with Nigeria Farmers.

According to Evbuomwan (2016), in response to the present Federal Ministry of Agriculture and Rural Development Green initiative argued that the value chain is one that must be developed and sustained if the country will achieve food security and boosts its ailing economy through job creation and increased manufacturing. Evbuomwan who noted that funding was a critical factor in developing the agricultural value chain line, said the level of funding which the agricultural sector has received over the years has been inadequate. "Both the government and the financial institutions in the country have not given the agricultural sector adequate attention, despite the importance of this sector. Okoroafor (2016) also noted that the Nigerian agricultural sector has not been able to perform its assigned roles in economic development. To address this, the Central Bank of Nigeria had instituted intervention funds that would address the funding challenges of not only farmers but also the value chain of the agriculture sector. Okoroa for noted that the apex bank, having seen that total credit to agriculture was less than one percent of total credit among banks, had discovered that banks were reluctant to lend to farmers because they believed the farmers would not pay back. "To know why they don't pay back we had a meeting with farmers to know why and they said their yield is small and when they take the 
produce to the market there is nobody there to buy it from them. We came to the conclusion that agriculture in Nigeria can only succeed when everybody on the line is financed and when all the various phases are taken care of and that was how NIRSAL was given birth to," he said. The CBN had established the Nigeria Incentive-based Risk Sharing System for Agricultural Lending (NIRSAL) in 2010, following an agreement with the Alliance for a Green Revolution in Africa (AGRA) to address the weakness of existing agricultural financing schemes. NIRSAL was an innovative mechanism for unlocking finance to serve the needs of all farmers, particularly smallholder farmers, agro-processors, agribusinesses as input suppliers in the agricultural value-chain. The aim was to provide farmers with affordable financial products while reducing the risk of loans to farmers offered by the financial institutions. The scheme was designed to build the capacity of banks to lend to agriculture, deploy risk sharing instruments to lower risks of lending, and develop a rating scheme for banks based on their commitment to lending to the agricultural sector. It was built on five major pillars, risk sharing facility, insurance, technical assistance, bank incentive and agricultural bank rating.

Tombofa (2004), states that the state of agriculture is of paramount importance to the development process. He pointed out that agriculture provides the basis for the world's great civilization in the past and the increase in agricultural productivity in England laid the basis for, and sustained the first industrial revolution. The agricultural sector is known to employ over 75 percent of the labour force in developing countries and provide the purchasing power over industrial goods. Todaro and Smith (2003) put it that if development is to take place and become self-sustaining; it will have to include the rural area in general and the agricultural sector in particular. "Traditionally, the role of agriculture in economic development has been as passive and supportive". Based on the historical experience of Western countries economic development was seen as requiring a rapid structural transformation of the economy focused on agricultural activities to a more complex modern industrial and services society. As a result, agriculture's primary role is to provide food and manpower to the expanding industrial economy.

Iganiga and Unemhilin (2011) studied the effect of federal government agricultural expenditure and other determinants of agricultural output on the value of agricultural output in Nigeria. A Cobb Douglas Growth Model was specified that included commercial credits to agriculture, consumer price index, annual average rainfall, population growth rate, food importation and GDP growth rate. The study performed comprehensive analysis of data and estimated the Vector Error Correction model. Their results showed that federal government capital expenditure was found to be positively related to agricultural output. Oji-Okoro (2011) employed multiple regression analysis to examine the contribution of agricultural sector on the Nigerian economic development. They found that a positive relationship between Gross Domestic Product (GDP) vis a vis domestic saving, government expenditure on agriculture and foreign direct investment between the period of 1986-2007. It was also revealed in the study that $81 \%$ of the variation in GDP could be explained by Domestic Savings, Government Expenditure and Foreign Direct Investment. Using time series data, Lawal (2011) attempted to verify the amount of federal government expenditure on Agriculture in the thirty-year period 1979 2007. Significant statistical evidence obtained from the analysis showed that government spending does not follow a regular pattern and that the contribution of the agricultural sector to the GDP is in direct relationship with government funding to the sector. Ukeji (2003) submits that in the 1960"s, agriculture contributed up to $64 \%$ to the total GDP but gradually declined in the 70 "s to $48 \%$ and it continues in 1980 to $20 \%$ and $19 \%$ in 1985, this was as a result of oil glut of the 1980s.Several large scale agricultural projects in Nigeria specializing in the production of grains, livestock, dairies and animal feeds, to mention but a few, were established. The Nigerian Agriculture and Co-operative Bank (NACB) was established in 1973 as part of government efforts to invest oil wealth into the agricultural sector through the provision of credit facilities to support agriculture and agro-allied businesses (Olagunju, 2000). By 1995 the bank had granted the sum of $\$ 3,179.6$ million as loan to the private sector. The River Basin Development Authorities (RBDAs) the development of river basins was conceived in 1963 with involvement in the Lake Chad Basin and River Niger Commissions for countries bordering the Lake and the Niger

In summary, the literatures reviewed so far have revealed some gaps to be filled. One of such gap is that from the studies reviewed in the literature, nobody has investigated the relationship between credit facilities and agricultural development in Adamawa State, North East Nigeria. In the light of the above, there is need for stronger empirical evidence on the relationship between bank credits to the agricultural development in Nigeria.

The dearth of much empirical work done on this area of study, the need to close this gap claim the attention of this study.In attempting to fill this gap, the study adopted the loan price theory which in economics posits that input determines output. Credit is essential for agricultural development and is often a key element of agricultural modernization. It has been primarily seen to promote agricultural production and increase income to farmers. However, access to credit is limited in rural areas and the majority of poor small-scale farmers are excluded from credit systems in Nigeria. The rate of obtaining loans from the formal financial institutions in the developing countries by rural borrowers is low due to the complicated and lengthy procedures that overwhelm the poor and uneducated farmer-borrowers. In other cases, credit problems which have restricted them from borrowing include commodity-specific credit, lack of participation in planning agricultural credit programmes, lack of or inadequate, financial institutions in the rural areas, and late releases of loans which make them to borrow from the informal sources.

\section{Research Methodology and Sample Size}

The study is designed to be totally a micro study on credit facility and its effect on the agricultural development in Adamawa State, North East Nigeria. The research adopted the survey analytical method and binary regression estimation technique. 


\section{Sample Size}

A sample of 300 people was extracted from the population in each of the three local government areas of the three Senatorial Zones of the State using the systematic statistical sampling technique. The sample group was eventually subjected to interview for data generation. This advantage inhered from the fact that the sample constitutes a smaller group which is subjected to more intense examination. The systematic random/ probability sampling which was applied in this research was more time consuming and also more expensive. However, it has the advantage of reducing bias in the formation of the sample thereby enhancing adequate representation of the population by the sample. The data collected will be presented in tables. Descriptive, judgmental and statistical modes of analysis will be utilized.

\begin{tabular}{|c|c|c|}
\hline Category of Respondents & $\begin{array}{c}\text { Number of } \\
\text { Questionnaires } \\
\text { Distributed }\end{array}$ & $\begin{array}{c}\text { Number of } \\
\text { Questionnaires } \\
\text { Received. }\end{array}$ \\
\hline Maiha (Northern Senatorial Zone) & 100 & 43 \\
\hline Girei (Central Senatorial Zone) & 100 & 45 \\
\hline Ganye (Southern Senatorial Zone) & 100 & 62 \\
\hline
\end{tabular}

Table 1: Sample Size Showing Categories of Respondents

Source: Field Survey Data 2019

A total of three hundred copies of questionnaires were produced and randomly administered to respondents in three local government areas of Adamawa State, one local government from each of the three Senatorial Zones. From this figure, one hundred and fifty 150 copies representing $50 \%$ were returned to the researcher.

\section{Model Specification}

The model for this study was framed in line with the work carried out by Iganiga and Unemhilin (2011) on the effect of federal government agricultural expenditure and other determinants of agricultural output on the value of agricultural output in Nigeria using logistic regression analysis.

The model is hereby specified thus;

CGSA $=b_{0}+b_{1}$ SEX $+b_{2} A G E+b_{3} A C A Q+b_{4} L O S$

equation 1

$\mathrm{CBABL}=\mathrm{b}_{0}+\mathrm{b}_{1} \mathrm{SEX}+\mathrm{b}_{2} \mathrm{AGE}+\mathrm{b}_{3} \mathrm{ACAQ}+\mathrm{b}_{4} \mathrm{LOS}$

equation 2

$\mathrm{BCA}=\mathrm{b}_{0}+\mathrm{b}_{1} \mathrm{SEX}+\mathrm{b}_{2} \mathrm{AGE}+\mathrm{b}_{3} \mathrm{ACAQ}+\mathrm{b}_{4} \mathrm{LOS}$

equation 3

$\mathrm{GIS}=\mathrm{b}_{0}+\mathrm{b}_{1} \mathrm{SEX}+\mathrm{b}_{2} \mathrm{AGE}+\mathrm{b}_{3} \mathrm{ACAQ}+\mathrm{b}_{4} \mathrm{LOS}$

equation 4

Where;

CGSA =Credit Guarantee Schemes on Agriculture

$\mathrm{CBABL}=$ Central Bank of Nigeria Anchor Borrowers Loan

$\mathrm{BCA}=$ Bank Credits on Agriculture

GIS $=$ Government Intervention Schemes

$\mathrm{SEX}=\mathrm{Sex}$

AGE $=$ Age

ACAQ = Academic Qualification

LOS = Length of Service

$\mathrm{B}_{0}=$ Intercept

$\mathrm{b}_{1}, \mathrm{~b}_{2}, \mathrm{~b}_{3}$ and $\mathrm{b}_{4}$ are parameters

\section{Method of Data Collection and Sources of Data}

The data collected for the study was basically primary in nature where structured questionnaires were used to elicit information from the targeted audience. Data collected came mainly from questionnaires and oral interview on the impact of credit facility on agricultural development of Adamawa State as our case study where our questionnaires were distributed for proper responses to elicit relevant information for the study.

\section{Estimation Procedure}

The study examined the effect of bank credit on agricultural development in Adamawa State. There are many statistical tools that can be applied in surveys to determine relationships and significant differences between variables. Pearson Moment Correlation Coefficient statistical technique and binary outcomes logistic econometric technique were adopted as a tool for analysis of the data. Pearson moment correlation coefficient was used to determine relationship between the observed factors that impact on the agricultural development of Adamawa State. The data collected will be presented in tables. Descriptive, judgmental and statistical modes of analysis will be utilized involving the use of methodology described therein. 
10. Data Presentation and Analysis of Regression Result.4.2 Presentation of Results and Evaluation of Hypotheses

Question No: 1.Credit guaranty schemes on agriculture (CGSA) have impacted positively to the development of the agricultural sector in Adamawa State

\begin{tabular}{|cccccc|}
\hline Variable $\mid$ & Obs & Mean & Std. Dev. & Min & Max \\
cgsa $\mid$ & 149 & .4899329 & .5015846 & 0 & 1 \\
sex $\mid$ & 149 & 1.543624 & .4997732 & 1 & 2 \\
age $\mid$ & 149 & 38.2953 & 11.82388 & 18 & 60 \\
aca $\mid$ & 149 & 2.57047 & 1.122588 & 1 & 4 \\
los $\mid$ & 149 & 10.66443 & 2.798674 & 6 & 15 \\
\hline
\end{tabular}

Table 2: Summary of Descriptive Statistics of CGSA Model

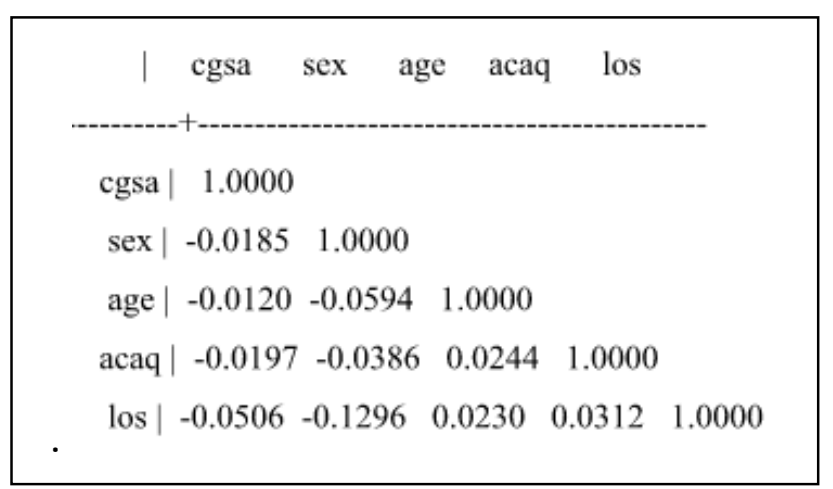

Table 3: Pairwise Correlation Coefficient Matrix of CGSA

- Analysis: Respondents were asked if credit guaranty schemes on agriculture (CGSA) have had any impact in the agricultural sector in Adamawa State

\begin{tabular}{|c|c|c|c|c|c|}
\hline & & Frequency & Percent & Valid Percent & Cumulative Percent \\
\hline Valid & agree & 31 & 20.7 & 68.7 & 20.7 \\
\cline { 2 - 6 } & undecided & 16 & 10.7 & 10.7 & 31.3 \\
\cline { 2 - 6 } & disagree & 103 & 68.7 & 20.7 & 100.0 \\
\cline { 2 - 6 } & Total & 150 & 100.0 & 100.0 & \\
\hline
\end{tabular}

Table 4: Effect of credit Guaranty Schemes on Agriculture (CGSA)

Source: Author's Computation from SPSS, 2019

\begin{tabular}{|l|c|c|c|}
\hline Variables & Odds Ratio & z-statistics & Probability \\
\hline C & 1.144 & 0.13 & 0.900 \\
SEX & 0.751 & -0.85 & 0.393 \\
AGE & 1.013 & 0.97 & 0.330 \\
ACAQ & 0.908 & -0.61 & 0.544 \\
LOS & 1.016 & 0.28 & 0.777 \\
\hline \multicolumn{3}{|c|}{ Pseudo R $=0.021$ Prob(chi2) $=0.685$} & log likelihood=-101.57 \\
\hline \multicolumn{2}{|c|}{ Table 5: Logistic Regression Result for CGSA Model } \\
Source: Computation by Researcher Using Stata 13, 2019
\end{tabular}

\subsection{Interpretation of Results}

From the analysis presented in Table 5, (69\%) of the respondents agreed that the facilities have had an impact in the agricultural sector in the state. $(11 \%)$ were undecided. $21 \%$ of the respondents disagreed. Comparatively the majority of the respondents agreed that the credit facilities have any impact on the agricultural business. However from the Logistic regression results, the positive odds ratio for all the categories of respondents is an indication that majority of the respondents agreed that Credit Guaranty Schemes to Agricultural (CGSA) sector in Adamawa State will improve its output by $0.751,1.013,0.908$ and 1.016 units as suggested by respondents under sex, age, academic qualifications (ACAQ) and length of service (LOS) categories. The pseudo $\mathrm{R}^{2}$ of 0.021 is a good fit meaning that the categories (sex, age, academic qualification and length of service) are well specified.

- Question No:2 The Central Bank of Nigeria's anchor borrower's loan (CBABL) is a positive development in financing agricultural production in Adamawa State 


\begin{tabular}{|c|c|c|c|c|c|}
\hline Variable | & Obs & Mean & Std. Dev. & Min & Max \\
\hline cbabl| & 149 & .590604 & .4933808 & 0 & 1 \\
\hline $\operatorname{sex} \mid$ & 149 & 1.536913 & .5003173 & 1 & 2 \\
\hline age | & 149 & 39.02013 & 12.68403 & 18 & 60 \\
\hline $\mathrm{acaq} \mid$ & 149 & 2.442953 & 1.105163 & 1 & 4 \\
\hline $\operatorname{los} \mid$ & 149 & 10.38926 & 2.71311 & 6 & 15 \\
\hline
\end{tabular}

Table 6: Summary of Descriptive Statistics of CBCBL Model

\begin{tabular}{|c|ccccc|}
\hline cbabl sex age acaq los & ag \\
\hline cbabl | 1.0000 & & & & \\
sex $\mid$ & 0.1027 & 1.0000 & & & \\
age $\mid$ & -0.1034 & -0.0475 & 1.0000 & & \\
acaq $\mid$ & -0.0493 & 0.0435 & 0.0244 & 1.0000 & \\
$\operatorname{los} \mid$ & 0.0694 & -0.0156 & 0.0282 & -0.0376 & 1.0000 \\
\hline
\end{tabular}

Table 7: Pairwise Correlation Coefficient Matrix of CBABL

- Analysis: Respondents were asked if the Central Bank of Nigeria Anchor Borrowers Loans (CBABL) has enhanced agricultural production in Adamawa State

\begin{tabular}{|c|c|c|c|c|c|}
\hline & & Frequency & Percent & Valid Percent & Cumulative Percent \\
\hline Valid & agree & 104 & 69.3 & 69.3 & 69.3 \\
\cline { 2 - 6 } & undecided & 20 & 13.3 & 13.3 & 82.7 \\
\cline { 2 - 6 } & disagree & 26 & 17.3 & 17.3 & 100.0 \\
\cline { 2 - 6 } & Total & 150 & 100.0 & 100.0 & \\
\hline
\end{tabular}

Table 8: Effect of Central Bank of Nigeria Anchor Borrowers Loans

(CBABL)Agricultural Production in Adamawa State

Source: Author's Computation from SPSS, 2019

\begin{tabular}{|c|c|c|c|}
\hline Variables & Odds Ratio & z-statistics & Probability \\
\hline C & 1.065 & 0.06 & 0.954 \\
SEX & 1.208 & 0.57 & 0.569 \\
AGE & 0.999 & -0.03 & 0.975 \\
ACAQ & 0.962 & -0.26 & 0.793 \\
LOS & 0.976 & -0.41 & 0.684 \\
\hline
\end{tabular}

Table 9: Logistic Regression Result for CBABL Model

Source: Computation by Researcher Using Stata 13,2019

Pseudo R ${ }^{2}=0.02 \mid \operatorname{Prob}($ chi2 $)=0.306 \mid \log$ likelihood $=-102.98$

\subsection{Interpretation of Result}

Table 9 showed that (69\%) of the respondents totally agreed that the Central Bank of Nigeria anchor borrowers loan is a welcome development, (13\%) were undecided while $(17 \%)$ disagreed. The highest percentage of respondents could be attributed to those local farmers whose lives were positively touched by the scheme from the Central Bank in Adamawa State. From the Logistic regression results, the positive odds ratio for all the categories of respondents is an indication that majority of the respondents agreed that CBN Anchor Borrower's Loan (CBABL) in Adamawa State will improve its output by $1.21,0.99,0.96$ and 0.97 units as suggested by respondents under sex, age, academic qualifications (ACAQ) and length of service (LOS) categories. The pseudo $\mathrm{R}^{2}$ of 0.02 is a good fit meaning that the categories (sex, age, academic qualification and length of service) are well specified.

- Question No: 3 Bank Credits onAgriculture (BCA) has affected agricultural output in Adamawa State. 


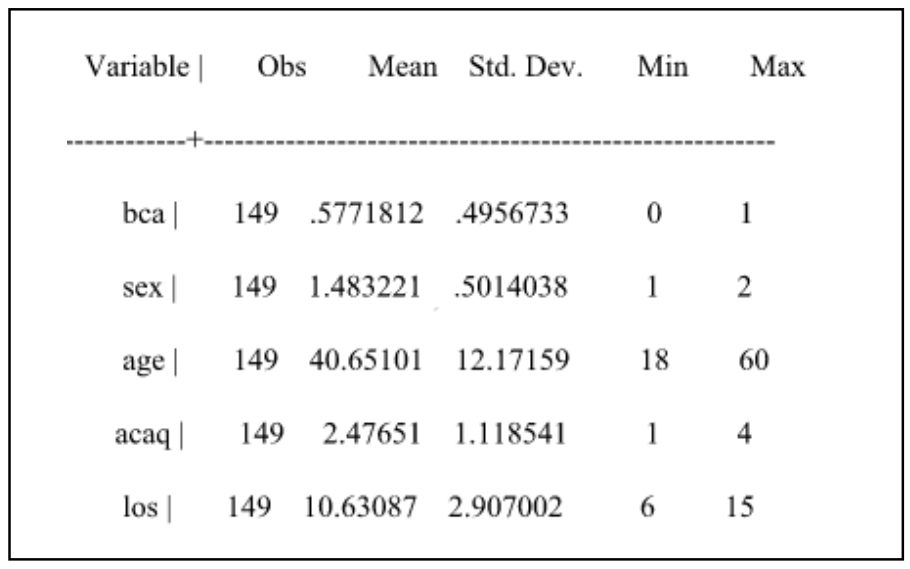

Table 10: Summary of Descriptive Statistics of BCA Model

\begin{tabular}{|c|ccccc|}
\hline & bca sex age acaq los & \\
bca $\mid$ & 1.0000 & & & & \\
sex $\mid$ & -0.0695 & 1.0000 & & & \\
age $\mid$ & 0.1736 & -0.0674 & 1.0000 & & \\
acaq $\mid$ & -0.0119 & 0.0565 & -0.0666 & 1.0000 & \\
$\operatorname{los} \mid$ & -0.0387 & -0.0112 & -0.0810 & 0.0524 & 1.0000 \\
\hline
\end{tabular}

Table 11: Pairwise Correlation Coefficient Matrix of BCA

- Analysis: Respondents were asked if Bank Credits on Agricultural (BCA) has affected agricultural output in the State

\begin{tabular}{|c|c|c|c|c|c|}
\hline & & Frequency & Percent & Valid Percent & Cumulative Percent \\
\hline \multirow{3}{*}{ Valid } & agree & 81 & 54.0 & 54.0 & 54.0 \\
\cline { 2 - 6 } & disagree & 69 & 46.0 & 46.0 & 100.0 \\
\cline { 2 - 6 } & Total & 150 & 100.0 & 100.0 & \\
\hline
\end{tabular}

Table 12: Showing Responses of Respondents on Agricultural Output Source: Author's Computation from SPSS, 2019

\begin{tabular}{|c|c|c|c|}
\hline Variables & Odds Ratio & z-statistics & Probability \\
\hline C & 0.286 & -1.11 & 0.266 \\
SEX & 0.757 & -0.81 & 0.415 \\
AGE & 1.006 & 0.49 & 0.622 \\
ACAQ & 1.065 & 0.39 & 0.695 \\
LOS & 1.164 & 2.30 & 0.022 \\
\hline \multicolumn{2}{|c|}{ Pseudo $\mathrm{R}^{2}=0.034 \quad$ Prob(chi2) $=0.410 \mid \log$ likelihood $=-98.53$} \\
\hline
\end{tabular}

Table 13: Logistic Regression Result for BCA Model

Source: Computation by Researcher Using Stata 13, 2019

\subsection{Interpretation of Result}

Table 13 indicated the percentage banks have aided agricultural production responses from the respondents fifty four percent (54\%) agreed that other credit facilities from other banks have aided agricultural production in Adamawa State. Forty six percent (46\%) disagreed. From the Logistic regression results, the positive odds ratio for all the categories of respondents is an indication that majority of the respondents agreed that Bank Credits on Agriculture (BCA) in Adamawa State will improve its output by $0.757,1.006,1.065$ and 1.164 units as suggested by respondents under sex, age, academic qualifications (ACAQ) and length of service (LOS) categories. The pseudo $\mathrm{R}^{2}$ of 0.034 is a good fit meaning that the categories (sex, age, academic qualification and length of service) are well specified.

- Question No: 4 Government Intervention Schemes (GIS) has ensured sustainable food security in Adamawa State. 


\begin{tabular}{|cccccc|}
\hline Variable | & Obs & Mean & Std. Dev. & Min & Max \\
\hline gis | & 149 & .5234899 & .5011324 & 0 & 1 \\
sex | & 149 & 1.550336 & .4991377 & 1 & 2 \\
age | & 149 & 36.98658 & 12.68804 & 18 & 60 \\
acaq | & 149 & 2.449664 & 1.153351 & 1 & 4 \\
los | & 149 & 10.36242 & 2.726781 & 6 & 15 \\
& & & & & \\
\hline
\end{tabular}

Table 14: Summary of Descriptive Statistics of GIS Model

\begin{tabular}{|l|lllll|}
\hline & gis $\quad$ sex age acaq los \\
gis $\mid$ & 1.0000 & & & \\
sex $\mid$ & 0.1100 & 1.0000 & & \\
age $\mid$ & -0.0552 & -0.1695 & 1.0000 & \\
acaq $\mid$ & 0.1043 & 0.1776 & 0.0664 & 1.0000 & \\
los $\mid$ & -0.0458 & -0.1872 & 0.0306 & -0.0629 & 1.0000
\end{tabular}

Table 15: Pairwise Correlation Coefficient Matrix of GIS

Analysis: Respondents were asked if Government Intervention Schemes (GIS) has ensured sustainable food security in Adamawa State.

\begin{tabular}{|c|c|c|c|c|c|}
\hline & & Frequency & Percent & Valid Percent & Cumulative Percent \\
\hline \multirow{6}{*}{ Valid } & Agree & 97 & 64.7 & 64.7 & 64.7 \\
\cline { 2 - 6 } & undecided & 23 & 15.3 & 15.3 & 80.0 \\
\cline { 2 - 6 } & disagree & 30 & 20.0 & 20.0 & 100.0 \\
\cline { 2 - 6 } & Total & 150 & 100.0 & 100.0 & \\
\hline
\end{tabular}

Table 16: Showing the Responses on Government Intervention

Source: Author's Computation from SPSS, 2019

\begin{tabular}{|c|c|c|c|}
\hline Variables & Odds Ratio & z-statistics & Probability \\
\hline C & 1.587 & -0.51 & 0.607 \\
SEX & 1.350 & 0.89 & 0.374 \\
AGE & 1.026 & 1.84 & 0.066 \\
ACAQ & 1.016 & 0.11 & 0.916 \\
LOS & 0.914 & -1.45 & 0.146 \\
\hline \multicolumn{2}{|c|}{ Pseudo R $\mathrm{R}^{2}=0.030$ Prob(chi2) $=0.397$} & $\log$ likelihood=-100.16 \\
\hline
\end{tabular}

Table 17: Logistic Regression Result for GIS Model

Source: Computation by Researcher Using Stata 13, 2019

\subsection{Interpretation of Results}

Sustainable food security could be a function of credit input to production, but Table 17 clearly indicates that (65\%) of the respondents agreed that it guarantees improved growth in production, (15\%) were undecided while (20\%) disagreed. From the Logistic regression results, the positive odds ratio for all the categories of respondents is an indication that majority of the respondents agreed that Government Intervention Schemes (GIS) in Adamawa State will improve its output by 1.350, 1.026, 1.016 and 0.914 units as suggested by respondents under sex, age, academic qualifications (ACAQ) and length of service (LOS) categories. The pseudo $\mathrm{R}^{2}$ of 0.030 is a good fit meaning that the categories (sex, age, academic qualification and length of service) are well specified. The research has been on the effect of credit facility on the agricultural development in Adamawa State North East Nigeria. 


\section{Summary of Findings}

The research which is made up of five chapters began with an introductory chapter. The second chapter reviews related literature, chapter three presents the research methodology, Chapter four presented and analysed the data while the fifth chapter concludes the research. The study adopted survey method in collecting and analysing the data with logistic Regression Analysis and Pearson correction Matrix. The study made the following findings:

- Agricultural output has a significant and positive impact on the level of economic growth in Adamawa State North East Nigeria.

- An increase in the output of the agricultural sector increases the level of economic growth of the Adamawa State economy.

- Credit guaranty schemes on agriculture (CGSA) have impacted positively to the development of the agricultural sector in Adamawa State

- The Central Bank of Nigeria's anchor borrower's loan (CBABL) is a positive development in financing agricultural production in Adamawa State

- Bank Credits onAgriculture (BCA) has affected agricultural output in Adamawa State positively.

- Government Intervention Schemes (GIS) has ensured sustainable food security in Adamawa State.

- Agriculture is the key driver to the economic growth recovery plan of Adamawa State Government and could create value chain on the domestic economy.

\section{Conclusion}

Finally, Nigeria cannot be proposing of becoming one of the leading twenty economies in the world by 2020, (vision20:20:20) when her productive, leadership and administrative capacities are questionable and engulfed by corruption. Therefore agriculture that once contributed over $60 \%$ to the gross domestic product GDP and highest employer of labor to succeed of becoming the key economic driver, government must remove all bottlenecks that may hinder smooth sail in promoting agricultural production and diversify the productive base of other sectors in Nigeria if the country must achieve her vision 20:20 initiative.

Since the research has been on the effect of credit facility to the agricultural sector. Agricultural sector development has been behind the success of industrialised countries such as Australia, USA China etc. In Nigeria, despite the numerous reforms in the agricultural sector, the output of the sector has not improved significantly due to negligence, corruption, security challenges and inconsistent agricultural policies. The result indicates that the output of the agricultural sector has the potentials of improving the level of economic progress in Nigeria. The result indicates that the high interest rate charged on agricultural loans have hindered the level of agricultural output and hence economic growth in Adamawa State. The result shows that if well organised bank credit to the agricultural sector could increase the level of economic wellbeing of Adamawa State Nigeria.

\section{Policy Recommendation}

The following recommendations are made from the results;

1. Concerted efforts should be made to increase the level of agricultural output in Nigeria by providing incentives to farmers.

- Government should increase the level of Credit guaranty schemes to farmers which will impact positively on the development of the agricultural sector in Adamawa State

- Awareness on the Central Bank of Nigeria's anchor borrower's loan should be made to farmers because of its positive impact on the development of agricultural production in Adamawa State

- Bank Credits on Agriculture particularly from Bank of Agriculture (BOA) should be increased at a reasonably low interest rate to boost agricultural output in Adamawa State.

- 4.Government Intervention Schemes such as Agricultural extension services should be enhanced to ensured sustainable food security in Adamawa State

\section{References}

i. Adegbaju A. A and F.O Olokoyo (2008) Recapitalization and Banks' Performance: A Case Study of Nigerian Banks. African Economic and Business Review Vol. 6 No. 1, ISSN 1109-5609

ii. Bernard, T (2009) "Banking sector openness and economic growth," Policy Research Working Paper Series 4019, The World Bank.

iii. Ijaiya, G.T. \& Abdulraheem, A. (2000).Commercial Banks Credits to the Agricultural Sector and Poverty Reduction in Nigeria. A Calibration Analysis. Nigeria Journal of Agricbiz and Rural Development. Vol.XL, No.12.

iv. Muftau, A.I. (2003). Commercial Bank Credit to the Agricultural Sector and the Nigerian Economy. An Analysis of the Future Trend. A Journal of Department of Business Administration.Vol.28, No.32.

v. Okoroafor, I (2016, October) Leadership Newspaper, P.3

vi. Evbuomwan, A (2016, October) Leadership Newspaper, P.3

vii. Okolo, D. A. (2004). "Regional Study on Agricultural Support Nigeria's Case”. Being Special study Report prepared for Food and Agricultural Organisation (FAO).

viii. Orji-Okoro, I. (2011). "Analysis of the Contribution of agricultural sector on the Nigerian economic development". World Review of business research, 1(1), 191-200. 
ix. Toby, A. J., and Peterside, D. B. (2014).Analysis of the Role of Banks in Financing the Agriculture and Manufacturing Sectors in Nigeria.International Journal of Research in Business Management,2(2), 9-22

x. Tomola, M. O., Adedisi, T. E. and Olawale, F. K. (2012). Bank Lending, Economic Growth and the performance of the Manufacturing Sector in Nigeria. European Scientific Journal, 8(3):19-34

xi. UNDP. (2008). MGDs in Nigeria: Current progress. Retrieved April 6, 2013, from http:/ / www.ng.undp.org/ mdgsngprogress.shtml.

xii. Yakubu, Z. and Affoi, A. Y. (2014). An Analysis of Commercial Banks' Credit on Economic Growth in Nigeria. Current Research Journal of Economic Theory, 6(2), 11-15. 